\title{
PELINDIAN ALUMINA DAN BESI OKSIDA BIJIH BAUKSIT KALIMANTAN BARAT DENGAN METODE PELINDIAN ASAM KLORIDA
}

\section{Extraction of Alumina and Iron Oxide from West Borneo Bauxite by Hydrochloride Acid Leaching}

\author{
REZKY I. ANUGRAH dan HASUDUNGAN E. MAMBY \\ Puslitbang Teknologi Mineral dan Batubara \\ Jalan Jenderal Sudirman 623 Bandung 40211 \\ Telp. (022) 6030483, Fax. (022) 6003373 \\ e-mail: rezkyia.2407@gmail.com
}

\begin{abstract}
SARI
Pada umumnya industri alumina menggunakan proses Bayer untuk mengekstraksi alumina bijih bauksit. Namun proses ini menghasilkan limbah red mud yang sangat besar jumlahnya, sehingga diperlukan teknologi alternatif untuk mengekstraksi bijih bauksit tersebut. Pelindian dengan asam dapat mengekstraksi berbagai jenis mineral bauksit dan tidak menghasilkan red mud. Serangkaian percobaan dan analisis dilakukan untuk mempelajari perilaku pelindian bijih bauksit Tayan, Kalimantan Barat menggunakan asam klorida tanpa melakukan proses pemanggangan atau roasting bauksit terlebih dahulu. Tujuan penelitian ini adalah mempelajari pengaruh variasi ukuran partikel bauksit, konsentrasi asam klorida, suhu pelindian dan persen padatan pada proses pelindian terhadap persen ekstraksi AI dan Fe. Persen ekstraksi Al dapat mencapai 90,26\% dan Fe 98,95\% pada kondisi suhu pelindian $100^{\circ} \mathrm{C}$, konsentrasi asam klorida $15 \%$, persen padatan $10 \%$ dan ukuran partikel -270 mesh.
\end{abstract}

Kata kunci: bauksit, ekstraksi, pelindian asam

\begin{abstract}
The aluminum industry generally uses a Bayer process to extract the alumina from the bauxite. However, this process generates an enormous quantity of toxic waste known as "red-mud", so the alternative process to extract alumina from bauxite is required. Acid leaching process can treat any bauxite minerals without generating redmud. Several experiments and tests had been conducted to study the leaching behaviour of bauxite ore from Tayan, West Borneo, with hydrochloric acid without roasting the ore. This research aims to study the effect of particle size, $\mathrm{HCl}$ concentration, leaching temperature and percent solid on the leaching rate of $\mathrm{Al}$ and Fe. Under the leaching conditions as follows: -270 mesh ore size, $100^{\circ} \mathrm{C}$ temperature, $10 \%$ percent solid and $15 \%$ $\mathrm{HCl}$ concentration; the extraction of $\mathrm{Al}$ and $\mathrm{Fe}$ are $90.26 \%$ and $98.95 \%$ respectively.
\end{abstract}

Keywords: bauxite, extraction, acid leaching

\section{PENDAHULUAN}

Indonesia memiliki sumberdaya dan cadangan bijih bauksit melimpah. Data Pusat Sumber Daya Mineral, Batubara dan Panas Bumi (2018) menunjukkan jumlah sumberdaya bauksit terukur di Indonesia sebesar 828.289.086 ton bijih dan 346.291.718 ton logam dengan cadangan terbukti sebesar 330.359.053 ton bijih dan 82.048.630 ton. Cadangan bijih bauksit ini tersebar terutama di 
Propinsi Kepulauan Riau, Kalimantan Barat dan Kalimantan Tengah.

Dengan berlakunya Undang-Undang No. 4 tahun 2009 dan peraturan turunannya yaitu Peraturan Menteri (PERMEN) ESDM No. 25 tahun 2018, peraturan ini mewajibkan para pemegang Izin Usaha Pertambangan (IUP) Operasi Pertambangan (OP), IUP Khusus (IUPK) OP dan IUP OP khusus pengolahan dan/atau pemurnian harus melakukan kegiatan pengolahan dan/atau pemurnian di dalam negeri. Untuk komoditas mineral bauksit, batasan minimum pengolahan dan pemurnian di dalam negeri yang produk akhirnya boleh diekspor adalah produk smelter grade alumina, chemical grade alumina, alumina hidrat, proppant dan logam Al.

Saat ini, PT. Indonesia Chemical Alumina (ICA) yang merupakan perusahaan patungan antara PT. Antam dan Showa Denko K.K. Jepang telah selesai membangun pabrik ekstraksi alumina dengan kapasitas sekitar 300.000 ton produk CGA (Chemical Grade Alumina) per tahun di Tayan, Kalimantan Barat (Miraza, 2012). Pabrik ekstraksi alumina ini menggunakan proses Bayer yang sudah umum dilakukan terhadap bijih bauksit yang mengandung mineral gibsite $\left(\mathrm{Al}_{2} \mathrm{O}_{3} .3 \mathrm{H}_{2} \mathrm{O}\right)$. Selain PT. ICA, PT. Well Harvest Winning (WHW) turut mengekstraksi alumina dalam bentuk SGA (Smelter Grade Alumina) dengan kapasitas 1.000.000 ton SGA per tahun.

Pada proses Bayer ini menyisakan limbah residu alumina atau red mud yang sangat besar jumlahnya, yakni sekitar 1 hingga 1,5 kali dari jumlah bijih bauksit yang diproses. Menurut Liu dan Wu (2012) sebanyak 0,8-1,5 ton red mud dihasilkan dari tiap 1 ton produksi alumina. Apabila pabrik ekstraksi alumina di Tayan berkapasitas 300.000 ton alumina per tahun, red mud yang dihasilkan nanti sekitar 240.000- 450.000 ton per tahun. Karena jumlah red mud yang dihasilkan sangat besar akan sangat menyulitkan dalam hal pembuangannya dan memerlukan tempat kolam penampungan yang sangat luas. Apabila kolam penampungan dibiarkan kering tentunya menimbulkan dampak polusi, sehingga perlu meminimalisasikan dengan memanfaatkan red mud salah satunya dengan membuatnya sebagai bata geopolimer. Red mud sendiri bersifat basa dan memiliki $\mathrm{pH}$ sekitar 10,5-12,5. Karena sifatnya ini dan jumlahnya yang sangat besar, red mud berpotensi membahayakan lingkungan apabila tidak dikelola dengan baik.

Saat ini ada metode alternatif untuk mengekstraksi alumina yaitu melindi bijih bauksit dengan larutan asam klorida. Proses ini dapat mengekstraksi berbagai jenis bijih bauksit seperti lempung bauksit dengan kadar alumina rendah dan bauksit kadar alumina tinggi dengan kadar silika yang tinggi. Proses ini tidak menghasilkan red mud, bahkan proses ini dapat mengekstraksi alumina dari red mud hasil proses Bayer. Selain mengekstraksi alumina, proses ini juga menghasilkan byproduct yang masih memiliki nilai ekonomi seperti besi oksida dan logam tanah jarang (Côté, Caudron dan Wilson, 2012; Borra $d k k$., 2015).

\section{Proses Ekstraksi Alumina dengan Metode Asam}

Salah satu proses alternatif untuk ekstraksi alumina dari bijih bauksit adalah dengan proses asam. Secara umum, diagram alir proses asam ditampilkan pada Gambar 1 .

Bauksit dipreparasi dengan penggerusan dan pemanggangan pada suhu sekitar $1200^{\circ} \mathrm{C}$ untuk mengubah mineral kaolin menjadi metakaolin. Unsur Al yang terkandung di dalamnya dapat terlarut sebagai garam asam. Bauksit yang telah dipanggang kemudian dilindi dengan larutan asam pada suhu didih atmosfer. Residu silika kemudian dipisahkan melalui sedimentasi dan penyaringan seperti pada proses Bayer. Garam besi yang terdapat pada filtrat dipisahkan dengan metode ekstraksi menggunakan senyawa organik. Aluminium hidroksida diperoleh melalui proses penguapan dan pendinginan sehingga terjadi kristalisasi.

Proses ekstraksi alumina dengan metode asam memiliki beberapa keuntungan dibandingkan proses Bayer karena dapat mengekstraksi besi dan tidak menghasilkan red mud karena residu hasil pelindian berupa serbuk silika. Namun proses ini memiliki beberapa kelemahan dibandingkan dengan proses Bayer. Energi yang digunakan pada proses ini sangat besar. Modal awal juga besar disebabkan larutan yang bersifat korosif. 


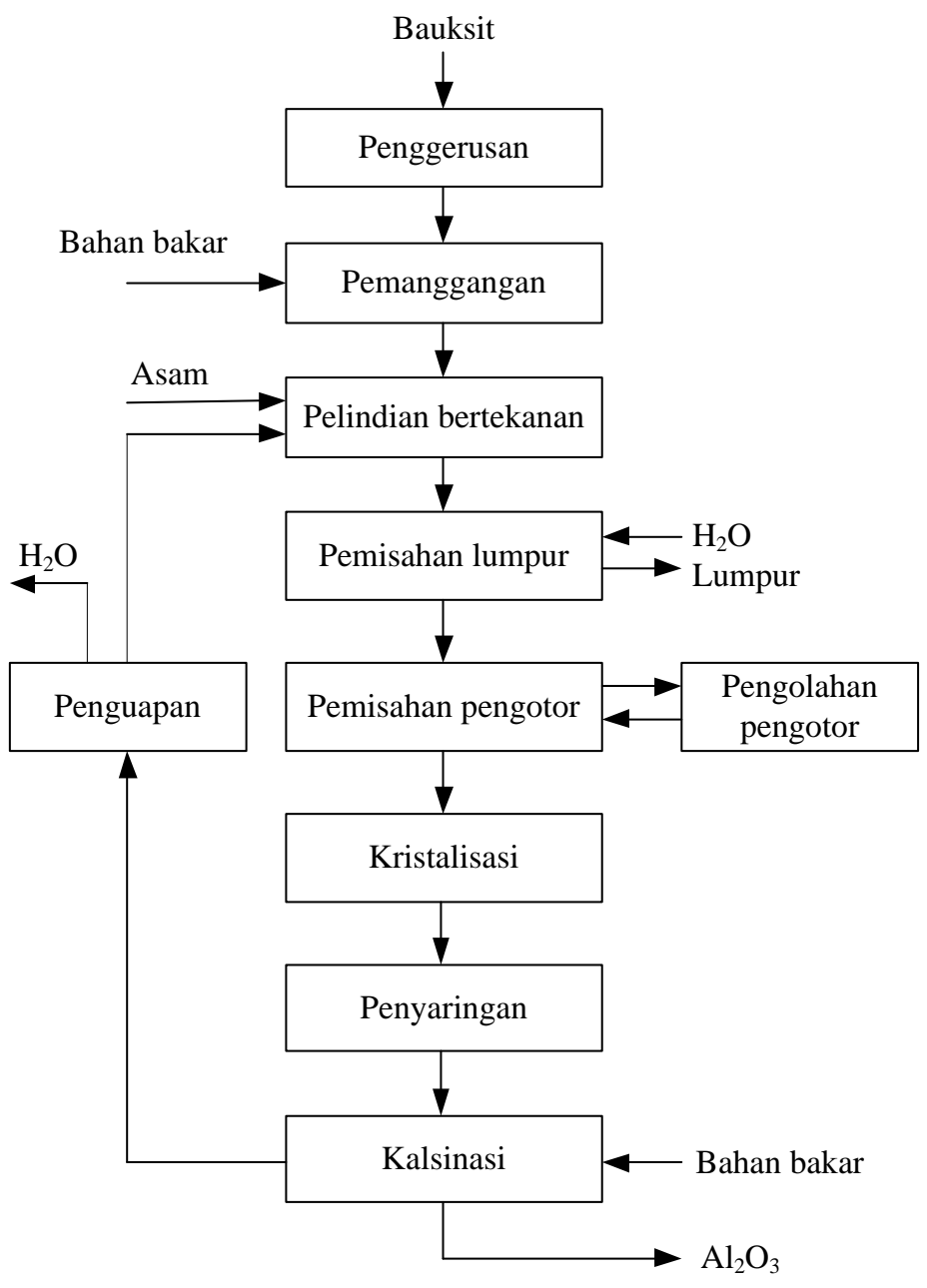

Gambar 1. Diagram proses asam secara umum (Habashi, 1997)

Beberapa peneliti mencoba mengembangkan metode ini agar lebih ekonomis dengan cara mengoptimalkan ekstraksi alumina dan besi serta memanfaatkan mineral berharga lainya seperti Salehi dkk. (2015), yang meneliti ekstraksi mineral besi dari bauksit menggunakan asam klorida. Zhao dkk. (2013) melakukan studi termodinamika pelindian bauksit jenis gibsit menggunakan asam klorida. Sultana, Gulshan dan Kurny (2014), mempelajari kinetika pelindian besi oksida pada lempung menggunakan asam oksalat dan asam klorida. Valeev dkk. (2016), meneliti ekstraksi Al pada bauksit jenis boehmit-kaolinit dengan cara pelindian asam klorida di dalam autoclave. Liu dan Wu (2012), juga melakukan penelitian pengaruh tekanan pada ekstraksi alumina dari bauksit kadar rendah menggunakan asam klorida. Pelindian pada kondisi atmosfer sebenarnya juga bisa dilakukan seperti yang dilakukan oleh Ghorbani dan Fakhariyan (2013), terhadap residu bauksit untuk mengekstraksi alumina dan besi oksida.

Beberapa penelitian mengunakan asam lainnya seperti asam sulfat yang dilakukan oleh Tariq $d k k$. (2014), namun perolehan Al sangat rendah. Ajemba dan Onukwuli (2012) dan Numluk dan Chaisena (2012), juga menggunakan asam sulfat dengan perolehan Al tinggi namun penelitiannya memerlukan proses kalsinasi suhu tinggi.

Pada skala komersial, sekarang ini telah dikembangkan proses Orbite yang menggunakan proses asam klorida dalam mengekstraksi alumina. Proses ini dikembangkan untuk memproduksi alumina dengan kemurnian tinggi (>99,99\% $\mathrm{Al}_{2} \mathrm{O}_{3}$ ). High Purity Alumina (HPA) Plant yang didirikan 
Orbite memulai produksi komersialnya pada 2013. Penelitian dan pengembangan proses ini menyimpulkan bahwa proses ini dapat digunakan pada berbagai tipe bijih dan mineral yang mengandung alumina, seperti lempung, bijih bauksit kadar rendah atau tinggi, nefelin, kaolin, abu terbang dan bahkan untuk red mud sendiri (Côté, Caudron dan Wilson, 2012).

Pada penelitian ini dilakukan proses ekstraksi Al dan Fe terhadap bijih bauksit asal Tayan, Kalimantan Barat. Tujuan penelitian adalah untuk mempelajari pengaruh variasi ukuran partikel bauksit, konsentrasi asam klorida, suhu pelindian dan persen padatan pada proses pelindian terhadap persen ekstraksi Al dan Fe. Pemurnian larutan kaya hasil ekstraksi memerlukan sejumlah proses selanjutnya agar logam Al dan Fe dapat diambil dengan mudah.

Serangkaian percobaan dan analisis dilakukan untuk mempelajari perilaku pelindian bijih bauksit menggunakan asam klorida tanpa melakukan proses pemanggangan bauksit terlebih dahulu dan dalam kondisi atmosfer. Penelitian dilakukan dengan beberapa variasi parameter percobaan seperti ukuran partikel bauksit, konsentrasi $\mathrm{HCl}$, suhu pelindian, persen padatan dan waktu pelindian.

\section{METODE}

Percontoh bijih bauksit yang digunakan dalam penelitian ini berasal dari daerah pertambangan PT. Antam di Tayan, Kalimantan Barat. Percontoh bijih yang dipakai sudah mengalami proses pencucian untuk mengurangi lempung yang melekat pada permukaan bijih sehingga kandungan $\mathrm{Al}_{2} \mathrm{O}_{3}$ dalam bijih meningkat. Bagan alir penelitian dapat ditunjukkan pada Gambar 2.

Bauksit tercuci selanjutnya dilakukan proses reduksi ukuran bijih menggunakan peremuk rol (roll crusher) dan pelumat bola (ball mill) yang dilanjutkan klasifikasi ukuran bijih dengan pengayakan. Ukuran partikel bijih yang digunakan dalam percobaan yaitu lolos ayakan 60, 100, 140, 200 dan 270 mesh. Percontoh bijih bauksit kemudian dianalisis komposisi kimianya dengan spektroskopi serapan atom atau atomic absorption spectrophotometer (AAS).
Analisis komposisi kimia bijih dengan AAS dilakukan pada setiap fraksi ukuran bijih. Identifikasi mineral yang dominan dalam percontoh bijih dilakukan dengan analisis X-Ray Diffraction (XRD). Analisis kandungan mineral dalam bijih juga dilakukan dengan mikroskop optik pada setiap fraksi ukuran bijih. Distribusi elemen dalam percontoh dan morfologi mineral dalam percontoh bijih dianalisis dengan scanning electron microscope (SEM).

Setelah karakterisasi percontoh bijih, kemudian dilakukan serangkaian percobaan pelindian di laboratorium dengan variabelvariabel independen yaitu persen padatan, suhu, ukuran partikel dan konsentrasi $\mathrm{HCl}$. Percobaan-percobaan dilakukan pada kecepatan pengadukan tetap $200 \mathrm{rpm}$. Dari percobaan yang dilakukan akan diperoleh data konsentrasi Al dan Fe terlarut dalam larutan hasil pelindian dengan analisis AAS sehingga dapat dihitung persen ekstraksi Al hasil pelindian dan persen ekstraksi Fe yang ikut terlarut. Dari hasil percobaan yang dilakukan dapat diperoleh persen ekstraksi Al dan Fe sebagai fungsi waktu dan diperoleh kondisi proses pelindian yang menghasilkan persen ekstraksi tertinggi. Persen ekstraksi Al dan Fe ditentukan dengan persamaan berikut:

Persen ekstraksi logam $=\frac{\text { Berat logam yang terlarut }}{\text { Berat awal logam pada percontoh }} \times 100 \%$

\section{HASIL DAN DISKUSI}

\section{Karakterisasi Bahan Baku}

Bauksit yang digunakan pada penelitian ini berwarna coklat muda kemerahan yang berarti bauksit mengandung mineral gutit dan hematit (Bardossy dan Aleva, 1990). Hal ini diperkuat dari hasil analisis XRD pada Gambar 3 yang menunjukkan bauksit yang digunakan memiliki komposisi mineral gibsit (G), gutit (Go), hematit (H) dan kuarsa $(\mathrm{Q})$ residu.

Selain keempat mineral tersebut, tampak lempung juga terlihat berikatan dengan gibsit yang terlihat pada hasil fotomikrograf sayatan tipis pada Gambar 4. Lempung yang berikatan kemungkinan besar adalah kaolinit yang merupakan silika reaktif. Selain itu terlihat kuarsa yang terinklusi dalam lempung tersebut. Bentuk partikel bijih jika dilihat dari hasil $X$ Ray mapping SEM pada Gambar 5 tampak 
berbentuk seperti bola yang didominasi unsur Al dan $\mathrm{O}$ yang terdistribusi merata pada permukaan bijih dan mengandung unsur lain seperti Si dan Fe. Nampak matriks O berwarna merah yang menandakan senyawa gibsit -
$\mathrm{Al}(\mathrm{OH})_{3}$, sedangkan Fe berwarna merah kecoklatan yang menandakan senyawa hematit $\left(\mathrm{Fe}_{2} \mathrm{O}_{3}\right)$. Adapun matriks $\mathrm{Si}$ berwarna hijau yang menandakan senyawa kuarsa $\left(\mathrm{SiO}_{2}\right)$.

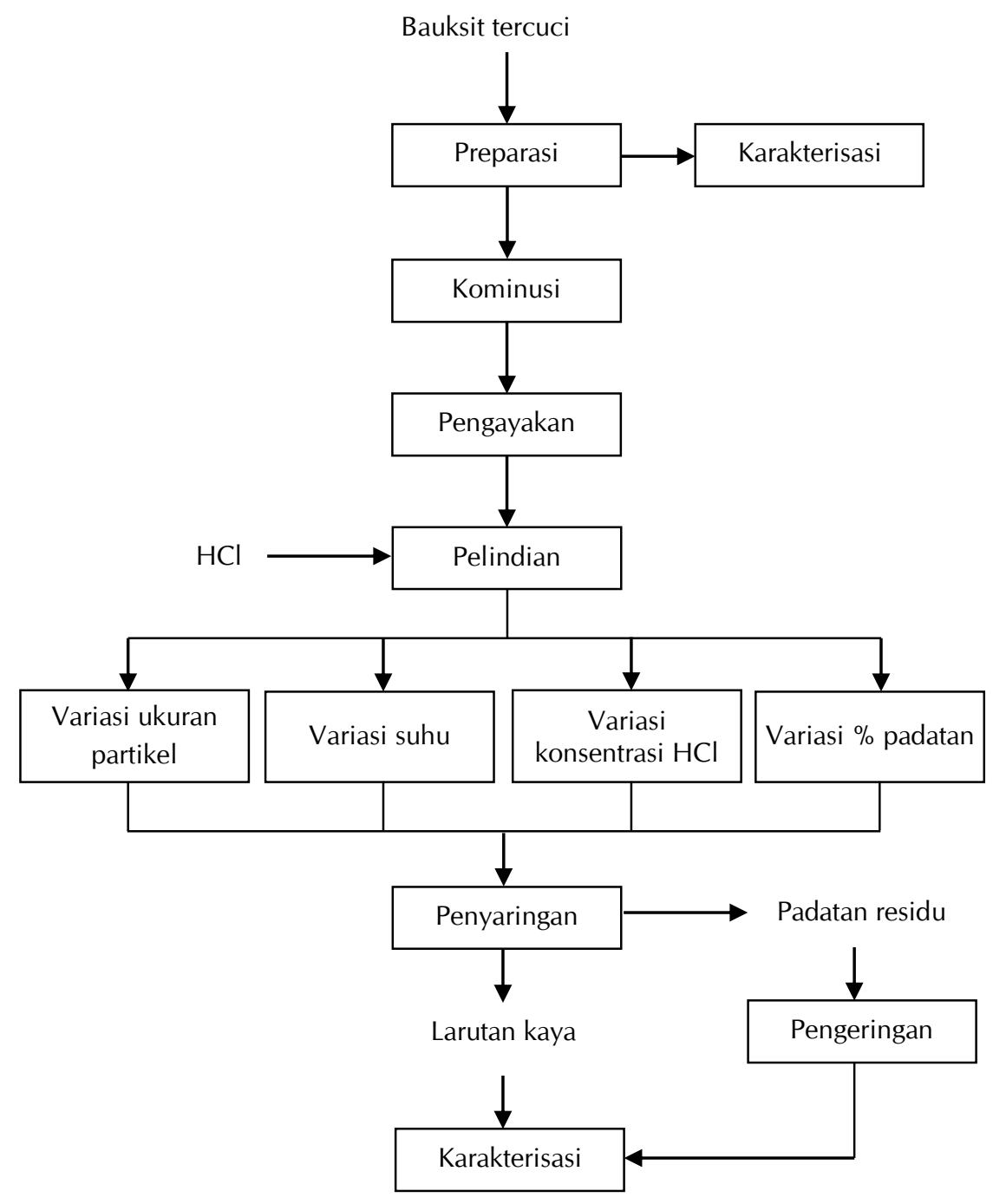

Gambar 2. Bagan alir penelitian

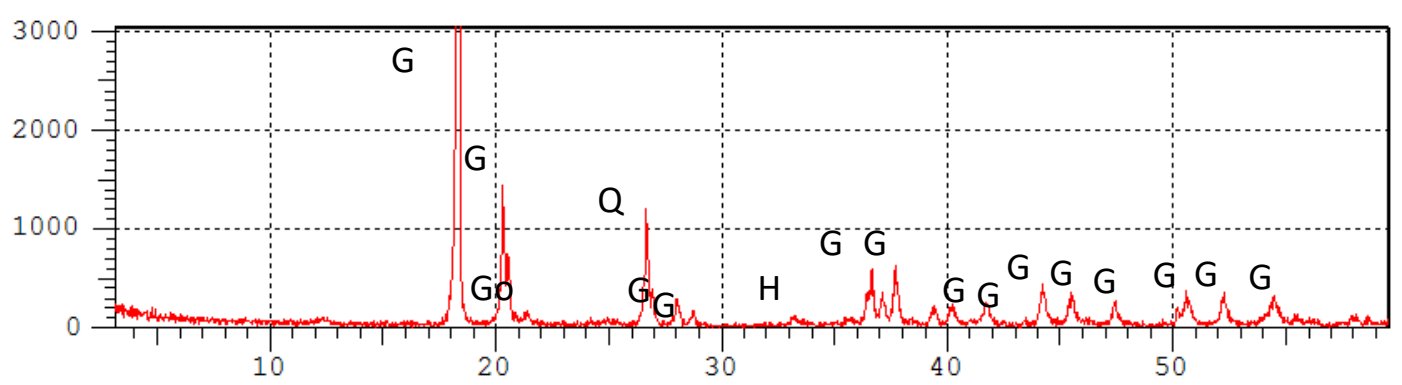

Gambar 3. Hasil analisis XRD bauksit tercuci 


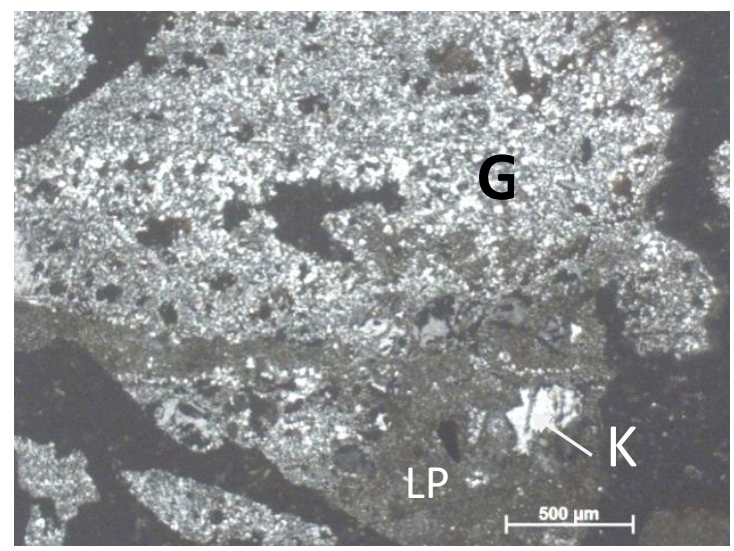

Gambar 4. Fotomikrograf sayatan tipis fraksi $+60 \#$ ( $\mathrm{G}=$ Gibsit, $\mathrm{LP}=$ Lempung, $\mathrm{K}=$ Kaolinit $)$
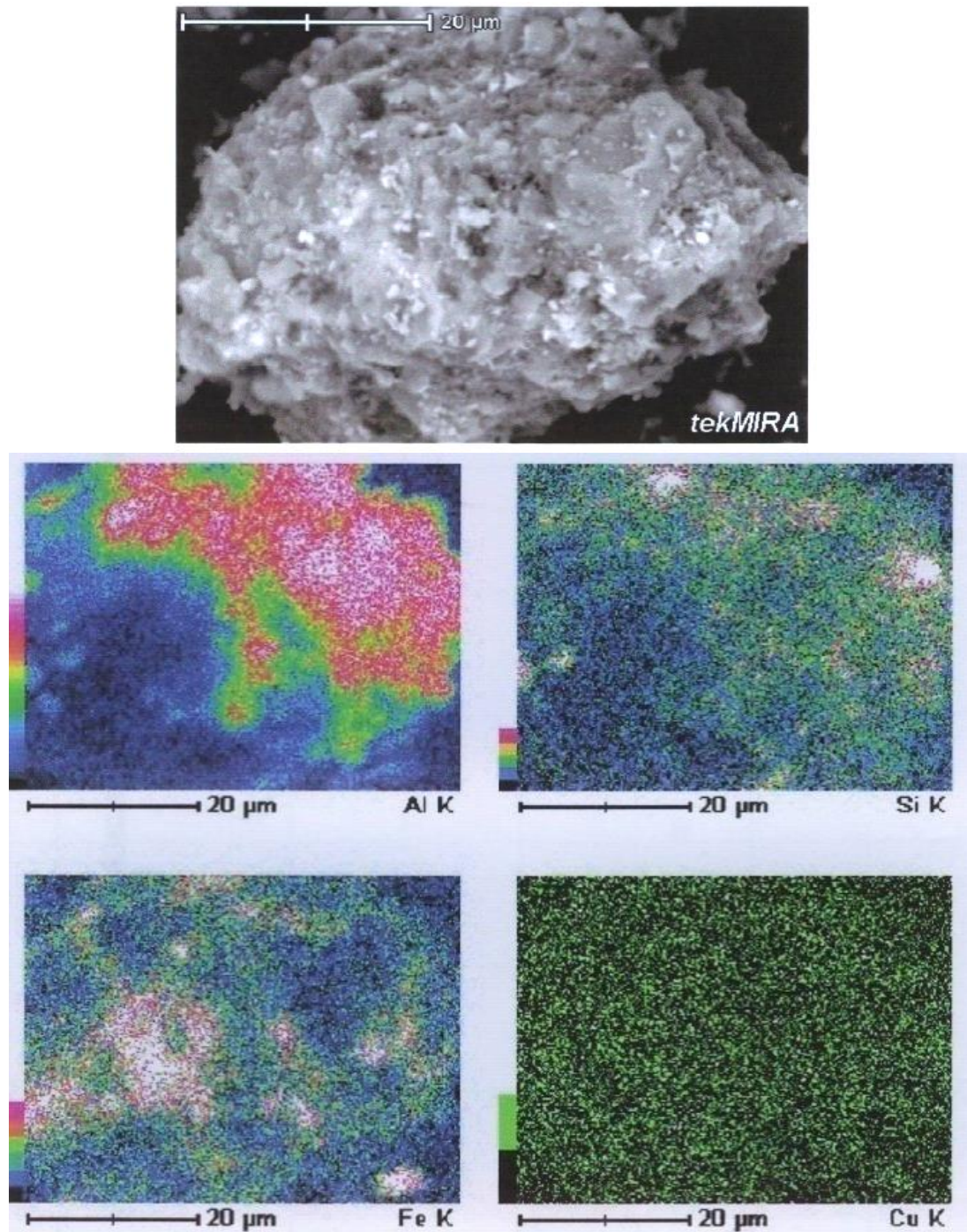

Gambar 5. X-Ray mapping bijih bauksit -60\# 
Komposisi mineral yang terkandung dalam bijih menunjukkan bahwa gibsit dominan dalam bijih bauksit tersebut. Mineral lain yang terdapat dalam bijih adalah gutit dan hematit yang merupakan mineral besi serta kuarsa. Kuantitas senyawa mineral penyusun diketahui dari analisis komposisi kimia yang ditunjukkan pada Tabel 1.

Menurut spesifikasi bauksit dan kegunaannya yang dibuat Peter (1984), komposisi kimia bauksit tercuci tersebut termasuk dalam bauksit metalurgi yang dapat digunakan sebagai bahan baku alumina smelter grade. Bauksit tercuci yang berukuran lebih dari $2 \mathrm{~mm}$ kemudian digerus hingga lolos ayakan 60 mesh lalu dilakukan analisis fraksi ukuran lolos ayakan 100, 140, 200 dan 270 mesh.

Percobaan pelindian bijih bauksit dengan $\mathrm{HCl}$ dilakukan pada berbagai variasi ukuran partikel bauksit, suhu pelindian, konsentrasi $\mathrm{HCl}$ dan persen padatan. Data kadar Al dan Fe pada berbagai fraksi ukuran, yang digunakan sebagai acuan pada perhitungan persen ekstraksi Al dan Fe, ditampilkan pada Tabel 2.

\section{Pengaruh Ukuran Partikel}

Pada percobaan pelindian ini salah satu variabel yang dipelajari adalah ukuran partikel bauksit yang dilindi. Ukuran partikel yang divariasikan adalah $-60+100,-100+140$, $140+200,-200+270$ dan -270 mesh. Kondisi tetap dalam percobaan adalah suhu pelindian $100^{\circ} \mathrm{C}$, konsentrasi $\mathrm{HCl} 10 \%(\mathrm{w} / \mathrm{w})$, persen padatan $10 \%$ dan kecepatan pengadukan 200 rpm. Hasil percobaan pengaruh ukuran partikel bauksit terhadap persen ekstraksi Al pada pelindian bauksit dengan $\mathrm{HCl}$ dapat dilihat pada Gambar 6.

Hasil percobaan menunjukkan bahwa persen ekstraksi Al meningkat dengan semakin kecilnya ukuran partikel bijih bauksit. Persen ekstraksi Al paling tinggi dicapai pada saat ukuran partikel -270 mesh.

Tabel 1. Komposisi kimia percontoh bijih bauksit tercuci

\begin{tabular}{ccccccccccc}
\hline Oksida & $\mathrm{Al}_{2} \mathrm{O}_{3}$ & $\mathrm{SiO}_{2}$ & $\mathrm{Fe}_{2} \mathrm{O}_{3}$ & $\mathrm{TiO}_{2}$ & $\mathrm{Na}_{2} \mathrm{O}$ & $\mathrm{CaO}$ & $\mathrm{K}_{2} \mathrm{O}$ & $\mathrm{P}_{2} \mathrm{O}_{5}$ & $\mathrm{MgO}$ & $\mathrm{LOI}$ \\
\hline Bijih bauksit tercuci & 53,8 & 7,06 & 5,52 & 0,51 & 0,28 & 0,059 & 0,049 & 0,031 & 0,029 & 28,2 \\
\hline
\end{tabular}

Tabel 2. Kadar $\mathrm{Al}_{2} \mathrm{O}_{3}$ dan $\mathrm{Fe}_{2} \mathrm{O}_{3}$ pada berbagai ukuran partikel

\begin{tabular}{cccccc}
\hline \multirow{2}{*}{ Oksida } & $-60+100 \#$ & $-100+140 \#$ & $-140+200 \#$ & $-200+270 \#$ & $-270 \#$ \\
\cline { 2 - 6 } & 46,7 & 42,2 & Kadar $(\%)$ & 44,7 \\
$\mathrm{Al}_{2} \mathrm{O}_{3}$ & 7,18 & 8,63 & 7,26 & 47,5 & 50,0 \\
$\mathrm{Fe}_{2} \mathrm{O}_{3}$ & 7,19 & 7,14 \\
\hline
\end{tabular}

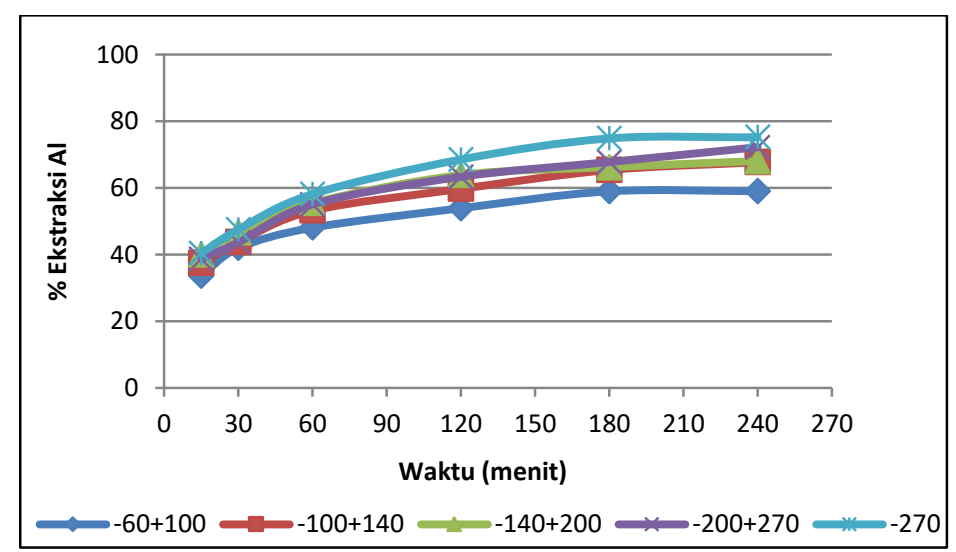

Gambar 6. Pengaruh ukuran partikel bijih bauksit terhadap persen ekstraksi $\mathrm{Al}$ (konsentrasi $\mathrm{HCl} 10 \%$, persen padatan $10 \%$, suhu $100^{\circ} \mathrm{C}$ ) 
Hasil percobaan pengaruh ukuran partikel bauksit terhadap persen ekstraksi Fe pada pelindian bauksit dengan $\mathrm{HCl}$ ditunjukkan pada Gambar 7. Hasil percobaan menunjukkan bahwa persen ekstraksi $\mathrm{Fe}$ meningkat dengan semakin kecilnya ukuran partikel bijih bauksit. Persen ekstraksi Fe paling tinggi dicapai pada saat ukuran partikel -270 mesh. Hal ini dikarenakan pada ukuran yang lebih halus luas permukaan kontak terjadinya reaksi semakin besar, sehingga reaksi pelindian semakin mudah terjadi.

\section{Pengaruh Suhu Pelindian}

Setelah mengetahui ukuran partikel yang dapat menghasilkan persen ekstraksi Al paling tinggi pada percobaan pelindian bijih bauksit, percobaan selanjutnya adalah mempelajari pengaruh suhu pelindian yang divariasikan pada temperatur $50,70,90,100$ dan $110^{\circ} \mathrm{C}$. Variabel tetap pada percobaan ini adalah ukuran partikel -270 mesh, persen padatan $10 \%$ dan konsentrasi asam 10\%. Menurut Arrhenius, peningkatan suhu akan meningkatkan laju reaksi pelindian sehingga dengan dengan waktu pelindian yang sama dengan suhu yang lebih tinggi maka persen ekstraksi logam akan semakin tinggi.

Pada suhu yang lebih tinggi ini maka akan menurunkan energi aktivasi proses pelarutan $\mathrm{Al}$, sehingga dalam selang waktu pelindian yang sama lebih banyak Al yang dapat dilarutkan. Hasil percobaan pengaruh suhu pelindian terhadap persen ekstraksi Al pada pelindian bauksit dengan $\mathrm{HCl}$ dapat ditunjukkan pada Gambar 8.

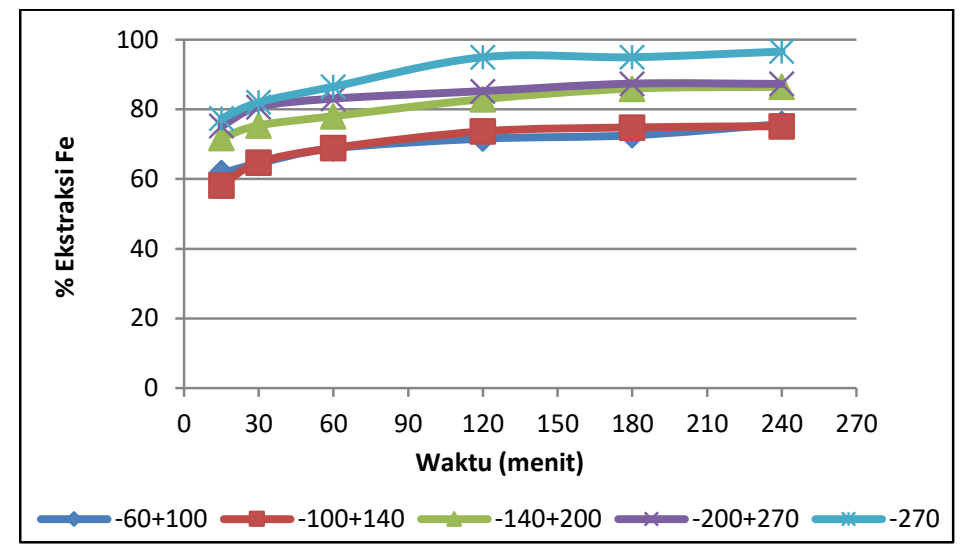

Gambar 7. Pengaruh ukuran partikel bijih bauksit terhadap persen ekstraksi Fe (konsentrasi $\mathrm{HCl} 10 \%$, persen padatan $10 \%$, suhu $100^{\circ} \mathrm{C}$ )

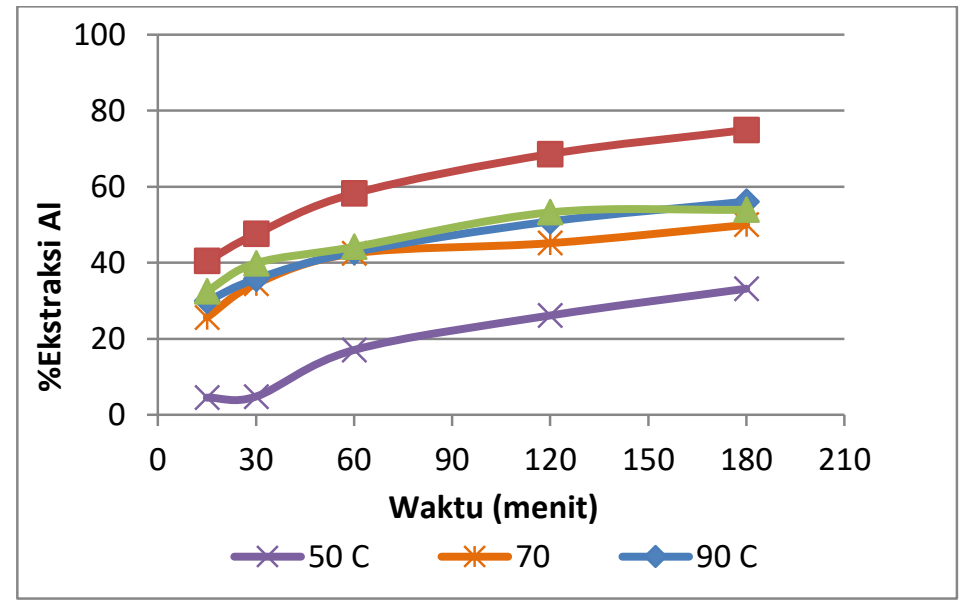

Gambar 8. Pengaruh suhu pelindian terhadap persen ekstraksi Al (ukuran partikel -270 mesh, persen padatan $10 \%$, konsentrasi $\mathrm{HCl} 10 \%$ ) 
Hasil percobaan menunjukkan bahwa persen ekstraksi Al meningkat dengan semakin tingginya suhu pelindian. Persen ekstraksi Al paling tinggi dicapai pada saat suhu $100^{\circ} \mathrm{C}$, namun ketika suhu pelindian dinaikkan menjadi $110^{\circ} \mathrm{C}$ persen ekstraksi Al menjadi turun. Hal ini dapat dikarenakan suhu pelindian yang mendekati titik didih $\mathrm{AlCl}_{3}$, yaitu $120^{\circ} \mathrm{C}$, sehingga $\mathrm{AlCl}_{3}$ menguap. Hal ini dapat dibuktikan pada terbentuknya $\mathrm{AlCl}_{3}$ yang terkondensasi di bagian bawah reflux, sehingga pengambilan percontoh pada reaktor pelindian tidak representatif untuk menghitung persen ekstraksi Al.

Hasil percobaan pengaruh suhu pelindian terhadap persen ekstraksi Fe pada pelindian bauksit dengan $\mathrm{HCl}$ ditunjukkan pada Gambar 9. Hasil percobaan menunjukkan bahwa persen ekstraksi Fe meningkat dengan semakin tingginya suhu pelindian. Berbeda dengan ekstraksi $\mathrm{Al}$, persen ekstraksi Fe paling tinggi dicapai pada saat suhu $110^{\circ} \mathrm{C}$, yaitu mencapai
98,19\%. Pada suhu ini $\mathrm{FeCl}_{3}$ diperkirakan tidak mengalami penguapan karena titik didihnya yang masih jauh, yaitu $315^{\circ} \mathrm{C}$. Namun pada rentang suhu $90-110^{\circ} \mathrm{C}$ persen ekstraksi Fe tidak mengalami perubahan secara signifikan, sehingga suhu pelindian dapat dikatakan optimum pada suhu $100^{\circ} \mathrm{C}$ untuk mengekstraksi Al dan Fe. Karena percobaan ini optimum pada suhu $100^{\circ} \mathrm{C}$, percobaan selanjutnya dilakukan pada suhu tersebut.

\section{Pengaruh Persen Padatan}

Untuk mengetahui pengaruh persen padatan pada pelindian bijih bauksit, pada percobaan selanjutnya persen padatan divariasikan pada rentang 7, 10 dan $12 \%$. Variabel tetap pada percobaan ini adalah konsentrasi $\mathrm{HCl} 10 \%$, suhu $100^{\circ} \mathrm{C}$ dan ukuran partikel -270 mesh. Hasil percobaan pengaruh persen padatan terhadap persen ekstraksi Al pada dapat ditunjukkan pada Gambar 10.

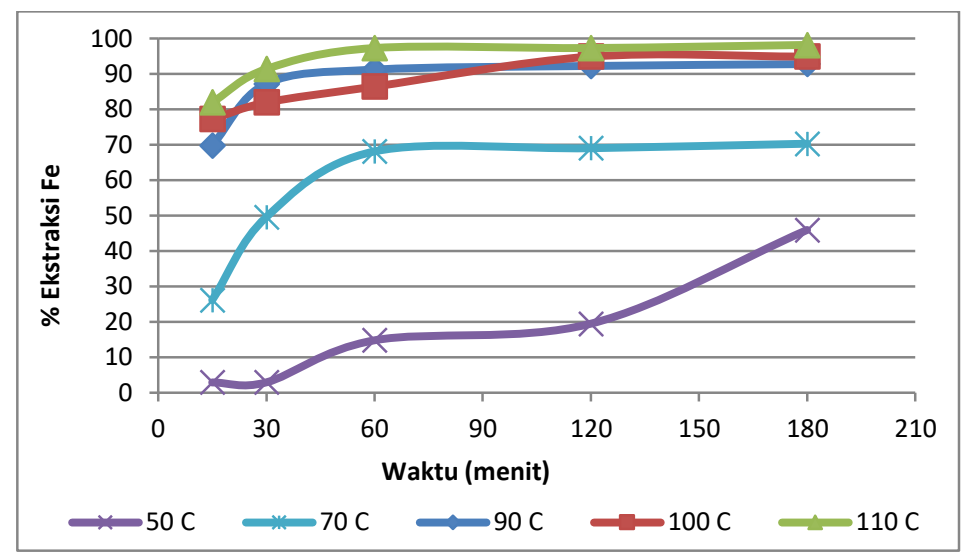

Gambar 9. Pengaruh suhu pelindian terhadap persen ekstraksi Fe (ukuran partikel -270 mesh, persen padatan $10 \%$, konsentrasi $\mathrm{HCl} 10 \%$ )

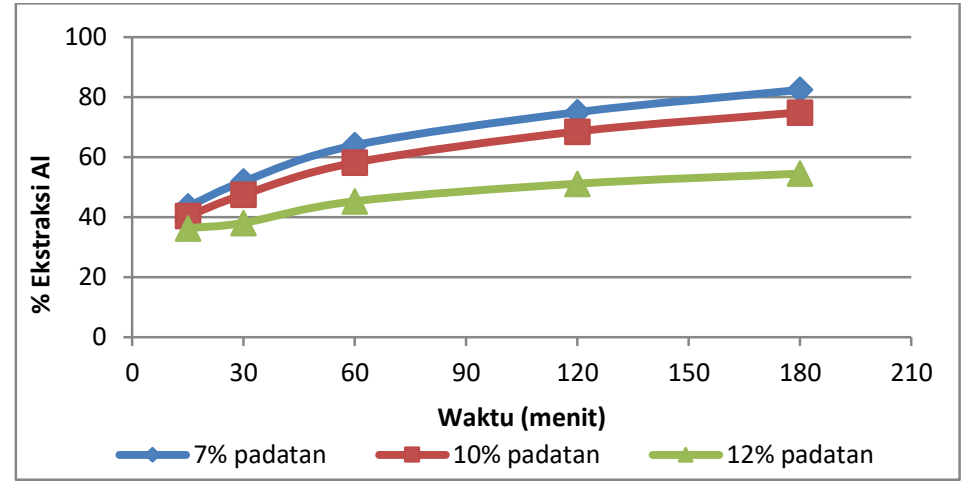

Gambar 10. Pengaruh persen padatan terhadap persen ekstraksi Al (ukuran partikel -270 mesh, konsentrasi $\mathrm{HCl} 10 \%$, suhu $100^{\circ} \mathrm{C}$ ) 
Hasil percobaan menunjukkan bahwa persen ekstraksi Al meningkat dengan semakin menurunnya persen padatan dari 12 hingga $7 \%$. Persen ekstraksi Al paling tinggi dicapai pada saat persen padatan $7 \%$ yang mencapai $82,46 \%$ pada waktu pelindian 180 menit. Penurunan persen ekstraksi yang signifikan didapat pada peningkatan persen padatan dari 10 menjadi $12 \%$. Pada persen padatan $12 \%$, persen ekstraksi $\mathrm{Al}$ yang paling tinggi sesudah 3 jam hanya mencapai $54,52 \%$. Hal ini disebabkan karena densitas slurry menjadi lebih tinggi sehingga mobilitas ion klorida menjadi turun. Selain itu dalam waktu yang sama pada konsentrasi asam klorida 10\%, jumlah gibsit dan besi oksida yang ikut mengkonsumsi asam lebih banyak, sehingga $\mathrm{Al}^{3+}$ yang dapat dilarutkan cenderung rendah.

Hasil percobaan pengaruh persen padatan terhadap persen ekstraksi Fe dapat ditunjukkan pada Gambar 11. Hasil percobaan menunjukkan bahwa secara umum persen ekstraksi Fe menurun dengan semakin tingginya persen padatan. Peningkatan persen padatan dari $7 \%$ menjadi $10 \%$ tidak memberikan pengaruh yang signifikan terhadap persen ekstraksi Fe sebagai fungsi waktu. Penurunan persen ekstraksi Fe yang signifikan didapatkan pada peningkatan persen padatan dari $10 \%$ menjadi $12 \%$. Pada persen padatan $12 \%$, persen ekstraksi Fe yang paling tinggi sesudah 3 jam hanya $68 \%$.
Secara umum semakin kecil persen padatan yang digunakan, akan semakin meningkat persen ekstraksi suatu logam. Persen padatan dalam pelindian ini akan menentukan kapasitas pelindian. Semakin kecil persen padatan, kapasitas pelindian dalam satuan berat bijih kering tiap satuan waktu yang akan diolah semakin rendah. Karena pertimbangan ini dan peningkatan persen ekstraksi $\mathrm{Al}$ dan $\mathrm{Fe}$ tidak terlalu signifikan dari persen padatan 10 ke $7 \%$, percobaan selanjutnya dilakukan pada persen padatan $10 \%$.

\section{Pengaruh Konsentrasi Asam Klorida}

Setelah mengetahui persen padatan yang optimum untuk mengekstraksi Al dan Fe pada percobaan pelindian bijih bauksit, percobaan selanjutnya adalah mempelajarai pengaruh konsentrasi asam klorida yang divariasikan pada rentang konsentrasi 7, 10 dan $15 \%$ (w/w). Variabel tetap pada percobaan ini adalah persen padatan $10 \%$, suhu $100^{\circ} \mathrm{C}$ dan ukuran partikel -270 mesh. Konsentrasi asam yang lebih kecil dari 7\% tidak dilakukan karena jauh dari kondisi stoikiometri. Sedangkan konsentrasi lebih dari $15 \%$ tidak dilakukan karena melihat penelitian Al-Zahrani dan Abdul-Majid (2009), pada konsentrasi $\mathrm{HCl} 6 \mathrm{M}$ (setara $\mathrm{HCl} 20 \%$ ) kurva persen ekstraksinya tidak lebih baik dibandingkan pada konsentrasi $\mathrm{HCl} 3 \mathrm{M}$. Keekonomian kebutuhan asam juga menjadi pertimbangan. Hasil percobaan pengaruh konsentrasi $\mathrm{HCl}$ terhadap persen ekstraksi $\mathrm{Al}$ pada dapat ditunjukkan pada Gambar 12.

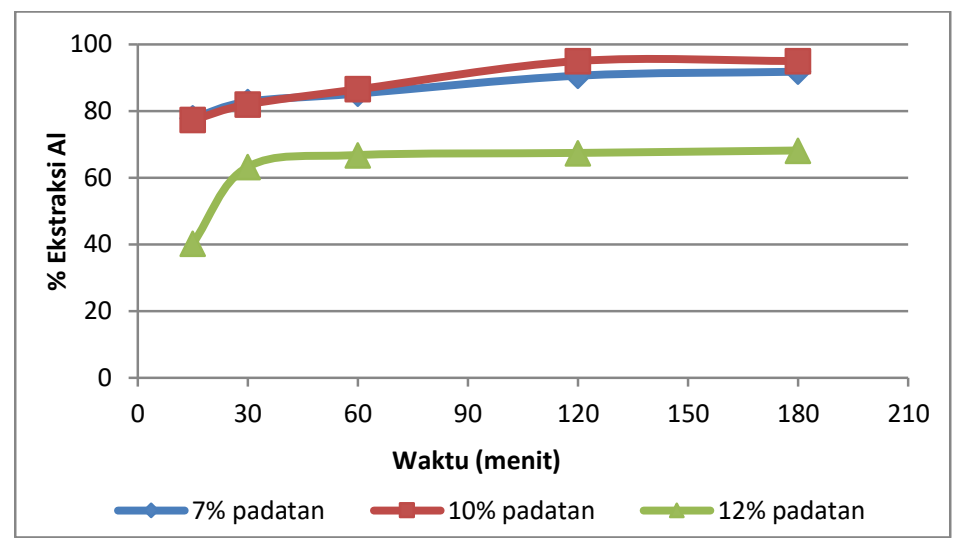

Gambar 11. Pengaruh persen padatan terhadap persen ekstraksi Fe (ukuran partikel -270 mesh, konsentrasi $\mathrm{HCl} 10 \%$, suhu $100^{\circ} \mathrm{C}$ ) 


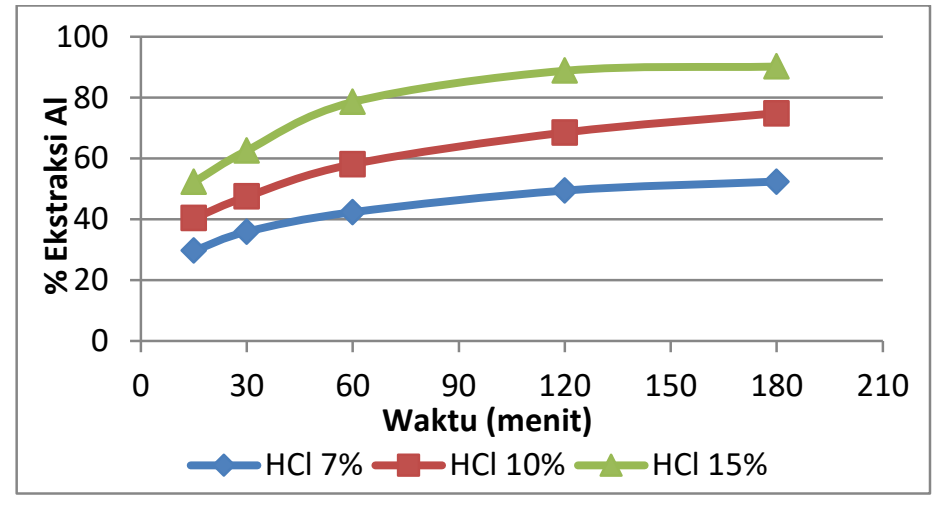

Gambar 12. Pengaruh konsentrasi $\mathrm{HCl}$ terhadap persen ekstraksi Al (ukuran partikel -270 mesh, persen padatan $10 \%$, suhu $100^{\circ} \mathrm{C}$ )

Hasil percobaan menunjukkan bahwa persen ekstraksi Al meningkat dengan semakin meningkatnya konsentrasi asam klorida dari 7 hingga 15\%. Persen ekstraksi Al paling tinggi dicapai pada saat konsentrasi asam klorida $15 \%$ yang mencapai $90,26 \%$ pada waktu pelindian mencapai 180 menit. Pada konsentrasi asam 7 dan $10 \%$, persen ekstraksi belum mencapai $80 \%$ pada rentang waktu pelindian. Untuk percobaan pengaruh konsentrasi $\mathrm{HCl}$ terhadap persen ekstraksi $\mathrm{Fe}$, hasilnya ditunjukkan pada Gambar 13.

Hasil percobaan menunjukkan bahwa persen ekstraksi Fe meningkat dengan semakin tingginya konsentrasi $\mathrm{HCl}$. Berbeda dengan ekstraksi Al, ekstraksi Fe terjadi secara cepat pada waktu 15 menit pertama. Persen ekstraksi Fe paling tinggi dicapai pada saat konsentrasi asam klorida $15 \%$ yang mencapai $98,95 \%$ pada waktu pelindian 180 menit. Kondisi terbaik percobaan ini ada pada konsentrasi $\mathrm{HCl} 15 \%$.

\section{Karakterisasi Residu}

Residu silika hasil percobaan pelindian dianalisis dengan XRD untuk menentukan senyawa yang terkandung di dalamnya yang dapat dilihat pada Gambar 14. Residu yang dianalisis adalah hasil percobaan pada kondisi optimum ukuran partikel -270 mesh, persen padatan $10 \%$, suhu $100^{\circ} \mathrm{C}$. Hasil analisis XRD menunjukkan bahwa komposisi utama residu adalah silika dengan masih ada kandungan alumina yang tidak terekstraksi. Selain itu juga terdapat $\mathrm{TiO}_{2}$ yang tidak bereaksi dengan asam pada proses pelindian.

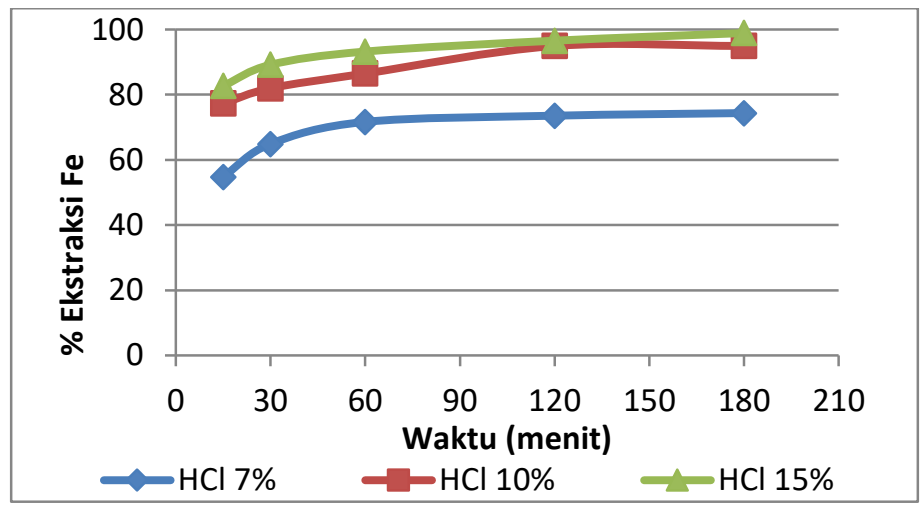

Gambar 13. Pengaruh konsentrasi $\mathrm{HCl}$ terhadap persen ekstraksi Fe (ukuran partikel -270 mesh, persen padatan $10 \%$, suhu $100^{\circ} \mathrm{C}$ ) 


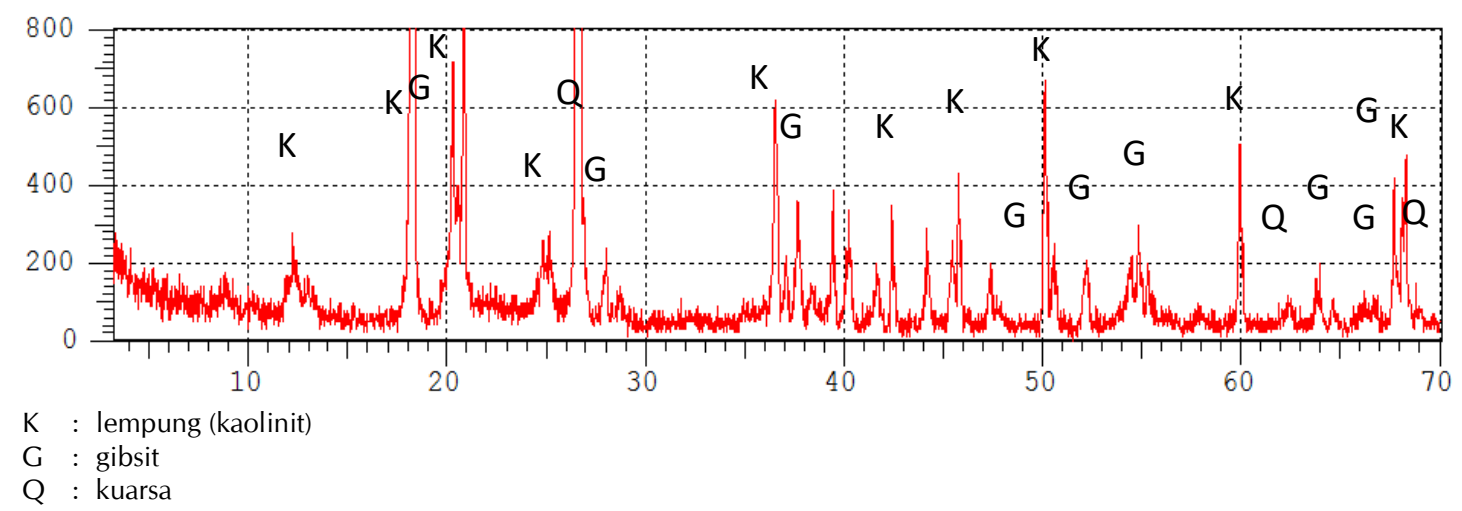

Gambar 14. Spektrum XRD residu hasil pelindian pada kondisi optimum (ukuran partikel -270 mesh, persen padatan $10 \%$ dan suhu $100^{\circ} \mathrm{C}$ )

Residu masih mengandung gibsit, lempung dari jenis kaolinit dan kuarsa namun sudah tidak mengandung gutit. Pada kondisi pelindian dengan partikel berukuran -270 mesh, persen padatan $10 \%$ dan suhu $100^{\circ} \mathrm{C}$, besi hampir larut seluruhnya sehingga tidak terdeteksi oleh analisis XRD, sedangkan aluminium dalam gibsit masih terkandung di dalam residu karena kelarutannya tidak sebesar besi dalam asam klorida.

\section{KESIMPULAN}

Ekstraksi Al dari bijih bauksit Tayan, Kalimantan Barat dapat dilakukan dengan melindinya menggunakan asam klorida tanpa dilakukan pemanggangan (roasting) terlebih dahulu. Komposisi utama residu adalah silika dengan kadar besi yang sedikit dan tidak bersifat kaustik dibandingkan pada proses Bayer, sehingga proses asam ini dapat menjadi teknologi alternatif untuk ekstraksi alumina dari bauksit.

\section{UCAPAN TERIMA KASIH}

Terima kasih diucapkan kepada Pusat Penelitian dan Pengembangan Teknologi Mineral dan Batubara atas dana penelitian yang diberikan, instansi-instansi lainnya dan individu-individu yang turut membantu pelaksanaan penelitian ini. Diharapkan penelitian ini bermanfaat bagi dunia penelitian Indonesia dan industri dalam negeri.

\section{DAFTAR PUSTAKA}

Ajemba, R. O. dan Onukwuli, O. D. (2012) “Process optimization of sulphuric acid leaching of alumina from Nteje clay using central composite rotatable design," International Journal of Multidisiplinary Science and Engineering, 3(5), hal. 1-7.

Al-Zahrani, A. dan Abdul-Majid, M. (2009) "Extraction of alumina from local clays by hydrochloric acid process," Journal of King Abdulaziz University-Engineering Sciences, 20(2), hal. 29-41. doi: 10.4197/Eng.20-2.2.

Bardossy, G. dan Aleva, G. J. J. (1990) Lateritic bauxites. Elsivier.

Borra, C. R., Pontikes, Y., Binnemans, K. dan Van Gerven, T. (2015) "Leaching of rare earths from bauxite residue (red mud)," Minerals Engineering, 76, hal. 20-27. doi: 10.1016/j.mineng.2015.01.005.

Côté, M., Caudron, G. dan Wilson, K. (2012) Orbite's Red Mud Remediation and Mineral Recovery Process. Secor.

Ghorbani, A. dan Fakhariyan, A. (2013) "Recovery of $\mathrm{Al} 2 \mathrm{O} 3, \mathrm{Fe} 2 \mathrm{O} 3$ and $\mathrm{TiO} 2$ from bauxite processing waste (red mud) by using combination of different acids," Journal of Basic and Applied Scientific Research, 3(1), hal. 187-191.

Habashi, F. (ed.) (1997) "General Principles," dalam Handbook of Extractive Metallurgy Volume II. Wiley-VCH. 
Liu, D.-Y. dan Wu, C.-S. (2012) "Stockpiling and comprehensive utilization of red mud research progress," Materials, 5(7), hal. 1232-1246. doi: 10.3390/ma5071232.

Miraza, T. (2012) Hilirisasi industri pertambangan dan road map pengembangan industri pengolahan dan pemurnian mineral nasional. Institut Teknologi Bandung.

Numluk, P. dan Chaisena, A. (2012) "Sulfuric acid and ammonium sulfate leaching of alumina from Lampang clay," E-Journal of Chemistry, 9(3), hal. 1364-1372.

doi: 10.1155/2012/758296.

Peter, H. W. (1984) The industrial minerals handbook. 2nd Ed. London: Division Metal Buletin PLC.

Pusat Sumber Daya Mineral Batubara dan Panas Bumi (2018) Data sumber daya dan cadangan bauksit. Jakarta: Pusat Sumber Daya Mineral, Batubara dan Panas Bumi.

Salehi, S., Noaparast, M., Shafaei, S. Z., Amini, A. dan Heidarnia, A. (2015) "Iron leaching from bauxite ore in hydrochloric acid using response surface methodology," Journal of Mining and Environment, 6(1), hal. 103-108. doi: 10.22044/JME.2015.363.
Sultana, U. K., Gulshan, F. dan Kurny, A. S. W. (2014) "Kinetics of leaching of iron oxide in clay in oxalic acid and in hydrochloric acid solutions," Materials Science and Metallurgy Engineering, 2(1), hal. 5-10.

Tariq, M., Iqbal, M. M., Aziz, A., Shafiq, M., Sajid, M. dan Mohammad, B. (2014) "Recovery of alumina from Khushab bauxite by leaching with sulphuric acid and removal of iron impurity by ethanol," Journal of the Chemical Society of Pakistan, 36(4), hal. 624-629.

Valeev, D., Pak, V., Mikhailova, A., Gol'Dberg, M., Zheleznyi, M., Dorofievich, I., Lainer, Y., Bychinskii, V. dan Chudnenko, K. (2016) "Extraction of aluminium by autoclave hydrochloric acid leaching of boehmitekaolinite bauxite," in Light Metals 2016. Cham: Springer International Publishing, hal. 23-28. doi: 10.1007/978-3-319-48251-4_5.

Zhao, A., Liu, Y., Zhang, T., Lü, G. dan Dou, Z. (2013) "Thermodynamics study on leaching process of gibbsitic bauxite by hydrochloric acid," Transactions of Nonferrous Metals Society of China, 23(1), hal. 266-270. doi: 10.1016/S1003-6326(13)62455-3. 
